\title{
PEMBANGUNAN TANAH WAKAF SECARA PENSWASTAAN: KAJIAN TERHADAP PROJEK MENARA IMARAH WAKAF OLEH MAJLIS AGAMA ISLAM WILAYAH PERSEKUTUAN
}

\section{Development of Waqf Land Through Privatisation: A Study on Menara Imarah Wakaf Project By Wilayah Persekutuan Islamic Religious Council}

\author{
Norliza Md Nuruddin ${ }^{1}$ \\ Hairunnizam Wahid ${ }^{2}$ \\ Aisyah Abdul-Rahman ${ }^{3}$
}

\begin{abstract}
Wilayah Persekutuan Islamic Religious Council (MAIWP) undertakes the development of waqf land through privatisation, funding from the government, or istibdal process. Development of waqf land through privatisation was undertaken on a piece of waqf land in Kuala Lumpur, owned by MAIWP, with land area of 1.2 acres. An istișnā' agreement was executed between MAIWP
\end{abstract}

1 Master Candidate, Faculty of Economics and Management, The National University of Malaysia, Bangi, norlizanordin@gmail.com

2 Senior Lecturer, School of Economics, Faculty of Economics and Management, The National University of Malaysia, Bangi, hairun@ukm.edu.my

3 Associate Professor, School of Economics, Faculty of Economics and Management, The National University of Malaysia, Bangi, eychah@ukm.edu.my 
and Lembaga Tabung Haji (LTH) for the project. Building construction cost of RM151 million was funded by LTH and the construction was completed in 2011. This project is expected to give returns of RM56.60 million from a lease to MAIWP for 25 years. Ownership of the building will be transferred to MAIWP at the end of the lease period. Land development through privatisation is expected to solve the main issue of most waqf land could not be developed by State Islamic Religious Council (SIRC) institutions due to the absence or insufficiency of funds. Hence, the objective of this study is to examine in detail the development model of waqf land through privatisation regarding compliance with rules and regulations as well as recording and disclosure in the financial statements of SIRC. This study used the library research and field study methods. Data were obtained from semi-structured interviews with MAIWP officers who were involved in the development of waqf land. The findings of the study showed that the development of waqf land complied with rules and regulations related to the development of waqf land. Nevertheless, this study found several areas for improvement by MAIWP particularly in the aspects of asset reporting and waqf returns. The implication of this study may be used as a starting point by MAIWP in formulating a Waqf Act to strengthen waqf management in Wilayah Persekutuan in particular and Malaysia in general. Besides, the need for a Framework on Waqf Reporting is critical since the existing framework for financial reporting is more appropriate for commerical use. Several recommendations and policy implications have also been suggested in this study.

Keywords: development of waqf land, privatisation, Menara Imarah Wakaf, waqf reporting

\section{PENGENALAN}

Wakaf merupakan antara institusi yang tertua dalam sejarah perkembangan Islam. Amalan melakukan wakaf sudah bermula sejak zaman Rasulullah SAW iaitu apabila baginda membina Masjid Quba' sebagai sebahagian daripada siri penting dalam misi perintah hijrah ke Madinah. ${ }^{4}$ Wakaf dari segi bahasa bermaksud menahan suatu harta daripada dibelanjakan. ${ }^{5}$ Dari segi istilah,

$4 \quad$ Osman Sabran, Pengurusan Harta Wakaf (Skudai: Penerbit UTM, 2002), 9.

5 Wahbah Zuhaily, Fiqh \& Perundangan Islam Jilid VIII, terj. Ahmad Shahbari Salamon et al. (Kuala Lumpur: Dewan Bahasa dan Pustaka, 2011), 177. 
wakaf menurut Abu Hanifah adalah menahan sesuatu harta dalam milik pewakaf dan disedekahkan manfaatnya untuk tujuan kebajikan. ${ }^{6}$ Seiring dengan perkembangan teknologi dan masa, terdapat pelbagai bentuk wakaf yang diperkenalkan. Antaranya adalah wakaf am, wakaf khas, wakaf tunai, wakaf saham, wakaf takaful dan wakaf korporat. Dalam konteks wakaf am, pewakaf tidak meletakkan sebarang syarat terhadap harta yang diwakafkan selagi harta tersebut digunakan ke arah kebajikan. Bagi wakaf khas pula, pewakaf mensyaratkan kepada pemegang amanah wakaf untuk kegunaan tertentu sahaja.

Pensyariatan wakaf tidak dinyatakan dengan jelas dalam al-Quran dengan menggunakan kalimah al-waqf. ${ }^{7}$ Walau bagaimanapun, terdapat dalil daripada al-Quran yang menyeru manusia agar berbuat baik untuk kepentingan masyarakat umum dan orang Islam khasnya dengan cara menyumbangkan sedekah mereka serta mendapat pahala yang berterusan. Antara dalil yang terdapat dalam al-Quran yang merujuk ibadah wakaf ini seperti firman Allah SWT:

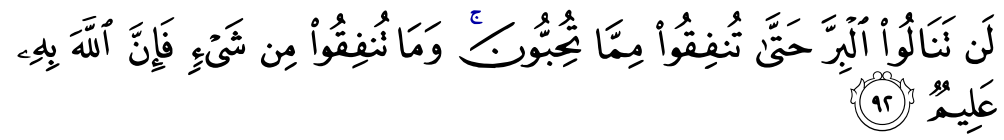

"Kamu sekali-kali tidak sampai kepada kebajikan (yang sempurna) sehinggalah kamu menafkahkan sebahagian harta yang kamu cintai. Dan apa-apa sahaja yang kamu (belanjakan) nafkahkan, maka sesungguhnya Allah maha mengetahui."

(Surah Āli ‘Imrān, 3: 92)

Sebaik sahaja mendengar ayat di atas, para sahabat Rasulullah SAW dan umat Islam yang kaya dan berharta berlumba-lumba untuk membuat kebajikan dengan mendermakan tanah-tanah dan kebun pertanian yang sangat mereka sayangi sebagai harta wakaf bagi mendapatkan keredaan Allah SWT. Selain itu, ada juga sahabat yang bukan dari golongan kaya juga sanggup memilih untuk menjadi miskin dan membelanjakan apa saja yang mereka ada. Bukti juga menunjukkan Rasulullah SAW bukan sahaja sangat menggalakkan amalan berwakaf tetapi baginda sendiri juga mengamalkannya. Antara dalil

\footnotetext{
Wahbah Zuhaily, Fiqh \& Perundangan Islam Jilid VIII, 177.

Hydzulkifli Hashim Omar, Azizi Abu Bakar, Mohd Sollehudin Shuib \& Mohd Kamal Azman Jusoh, 'Penggunaan Kaedah Bot dalam Usaha Membangunkan Tanah Wakaf Majoodsaw Pulau Pinang', The Islamic Endowment Seminar (Nilai, Universiti Sains Islam Malaysia , 2015).
} 
yang menunjukkan amalan wakaf dituntut dalam Islam ialah hadis Rasulullah SAW sepertimana berikut:

$$
\text { إذا مات ابن آدم انقطع عمله إلّا من ثلاث: صدقة جارية، وعلم ينتفع به، وولد }
$$

“Apabila mati seseorang anak Adam, maka terputuslah pahala amalannya kecuali tiga perkara iaitu sedekah jariah atau ilmu yang dimanfaatkan dengannya atau anak yang soleh yang mendoakannya." 8

Imam al-Rafi'ī telah mentafsirkan perkataan sedekah jariah dengan maksud wakaf kerana pahala sedekah jariah yang berterusan kepada orang yang melakukannya sedangkan sedekah yang lain pahalanya tidak berpanjangan mengalir seperti wakaf. Dalil lain yang menunjukkan bahawa amalan wakaf amat dituntut oleh Islam ialah apabila Rasulullah SAW memerintahkan Saidina 'Uthmān Ibn 'Affān membeli sebuah telaga milik Yahudi di Madinah. Telaga tersebut telah diwakafkan manfaatnya untuk seluruh umat Islam.

Di Malaysia, semua aset wakaf adalah terletak hak di bawah pengurusan di bawah Majlis Agama Islam Negeri (MAIN) berdasarkan Jadual ke Sembilan (Senarai Negeri) Perlembagaan Persekutuan. Perkara 74(2), Perlembagaan Persekutuan memperuntukkan bahawa negeri-negeri mempunyai kuasa untuk membuat undang-undang bagi perkara-perkara yang disebut di bawah senarai negeri yang terkandung di dalam senarai kedua Jadual ke Sembilan. ${ }^{9}$ Bagi tujuan penyelarasan, kerajaan telah menubuhkan Jabatan Wakaf, Haji dan Zakat (JAWHAR) untuk merancang dan menyelaras perkara berkaitan wakaf, haji dan zakat di peringkat Persekutuan. Matlamat penubuhan JAWHAR yang khusus untuk wakaf adalah untuk memelihara dan memastikan hartanah wakaf benar-benar memberi manfaat kepada masyarakat Islam dengan menyediakan keperluan yang sepatutnya untuk memajukan harta wakaf dari sudut dana dan perancangan yang baik. Walau bagaimanapun, JAWHAR tidak mempunyai kuasa undang-undang kerana ditubuhkan untuk tujuan pentadbiran. ${ }^{10}$ Oleh itu, Yayasan Wakaf Malaysia telah ditubuhkan pada tahun 2008 di bawah Akta Pemegang Amanah (Pemerbadanan) 1952 yang berperanan untuk

8 Muștafā Bughā, Mukhtașạar Șaḥịh Muslim, terj. Muhammad Amar Adly et al. (Johor: Binhalabi Press, 2013), 707.

9 Perkara 74(2), Perlembagaan Persekutuan

10 Syarifah Zubaidah Syed Abdul Kadir, 'Kerangka Undang-Undang Pengurusan Wakaf di Malaysia: Ke Arah Keseragaman Undang-Undang,' Kanun: Jurnal Undang-Undang Malaysia, vol. 28/1 (2016): 120. 
Pembangunan Tanah Wakaf Secara Penswastaan: Kajian Terhadap Projek Menara Imarah Wakaf oleh Majlis Agama Islam Wilayah Persekutuan

membangunkan tanah wakaf sedia ada dan mewujudkan hartanah wakaf baru melalui jalinan kerjasama dengan MAIN. ${ }^{11}$

Antara isu berkaitan tanah wakaf ialah isu kedudukan tanah wakaf, kekurangan dana untuk membangunkan tanah wakaf dan ketidakfahaman masyarakat tentang pembangunan tanah wakaf. ${ }^{12}$ Hasil dapatan ini disokong oleh kajian yang menyatakan kekurangan dana juga menjadi antara punca utama menyebabkan harta wakaf tidak dapat dibangunkan sebagaimana yang dinyatakan. ${ }^{13}$ Isu ini telah berlarutan agak lama di mana dapatan kajian lain juga menunjukkan dana yang besar diperlukan untuk menjalankan projek-projek pembinaan di atas tanah wakaf supaya niat pewakaf terlaksana sedangkan MAIN sendiri tidak mempunyai sumber yang mencukupi. ${ }^{14}$ Di Malaysia, dilaporkan masih terdapat beribu ekar tanah wakaf yang bernilai jutaan ringgit yang masih belum dibangunkan. ${ }^{15}$

Berdasarkan Laporan Ketua Audit Negara Negeri Kedah Tahun 2014, pelbagai teguran mengenai pengurusan wakaf Majlis Agama Islam Negeri Kedah selaku pemegang amanah tunggal telah dilaporkan. ${ }^{16}$ Antara teguran yang dibuat adalah berkenaan tanah wakaf yang berpotensi tetapi tidak dibangunkan, pencerobohan tanah wakaf dan data tanah wakaf tidak lengkap. Laporan Ketua Audit Negara Negeri Kelantan Tahun 2014 juga melaporkan mengenai tanah wakaf berpotensi tetapi belum dibangunkan dan tanah wakaf yang diceroboh. ${ }^{17}$ Sungguhpun Malaysia merupakan antara negara Islam yang dinamik bertaraf antarabangsa, pembangunan harta wakaf yang menggunakan

11 Yayasan Wakaf Malaysia, 'Laporan Tahunan Yayasan Wakaf Malaysia 2016,' https://ywm.gov.my, dicapai pada 30 April 2018.

12 Rohayati Hussin \& Rusnadewi Abdul Rashid, 'Isu-Isu Berkaitan Tanah Wakaf Halangan Kepada Institusi Wakaf Pendidikan Tinggi di Malaysia,' (Kertas kerja, Waqf Round Table Conference, 2015), 6.

13 Sanep Ahmad \& Nur Diyana Muhamed, 'Institusi Wakaf dan Pembangunan Ekonomi Negara: Kes Pembangunan Tanah Wakaf di Malaysia,' Prosiding Persidangan Kebangsaan Ekonomi Malaysia ke VI'(Bangi: Universiti Kebangsaan Malaysia, 2011).

14 Asmak Ab Rahman, 'Peranan Wakaf dalam Pembangunan Ekonomi Umat Islam dan Aplikasinya di Malaysia,' Jurnal Syariah, vol. 17/1 (2009): 144.

15 Mohd Haiyazid Mohammad \& Sanep Ahmad, 'Pembangunan Tanah Wakaf Melalui Hotel Wakaf: Strategi Lautan Biru Nasional,' (The Asean Islamic Endowment Seminar 2014), 563.

16 Jabatan Audit Negara, 'Laporan Ketua Audit Negara Negeri Kedah 2014,' 16, https://www.audit.gov.my, dicapai pada 15 April 2018.

17 Jabatan Audit Negara, 'Laporan Ketua Audit Negara Negeri Kelantan 2014,' 29, https://www.audit.gov.my, dicapai pada 15 April 2018. 
instrumen kewangan kontemporari berada pada tahap yang kurang memberangsangkan. ${ }^{18}$ Dua masalah utama yang dihadapi oleh MAIN Perak iaitu kekurangan dana dan kepakaran dapat di atasi dengan membangunkan tanah wakaf melalui beberapa kaedah pembangunan. ${ }^{19}$ Alternatif bentuk pembangunan baharu diperlukan bagi memastikan harta wakaf lebih produktif dan mengelakkan ianya tidak digunakan. Kontrak ijārah dan istiṣna ' dilihat sangat sesuai untuk membiayai pembangunan tanah wakaf. ${ }^{20}$

Pulau Pinang dan Wilayah Persekutuan Kuala Lumpur merupakan antara negeri yang terkehadapan dalam membangunkan harta wakaf secara komersial kerana kebanyakan harta wakaf yang terdapat di kedua-dua negeri tersebut terletak di kawasan yang berpotensi dan strategik untuk pembangunan. ${ }^{21}$ Pelaburan terbesar ialah hasil kerjasama antara MAIWP dan LTH bagi projek pembinaan bangunan 34 tingkat telah menjana pendapatan yang cukup lumayan kepada pentadbir yang akhirnya disalurkan untuk kepentingan rakyat. ${ }^{22}$ Pembangunan harta yang produktif dapat mengoptimumkan penggunaan harta tersebut dan penggunaannya dapat dimaksimumkan. ${ }^{23}$ Berdasarkan kejayaan pelaksanaan projek pembangunan secara penswastaan antara MAIWP dan LTH, wujud persoalan sama ada pembangunan projek yang bernilai tinggi ini boleh dijadikan model kepada institusi wakaf yang lain dari aspek pematuhan kepada undang-undang dan peraturan serta akauntabiliti terhadap pelaporan wakaf bagi meningkatkan keyakinan masyarakat terhadap institusi wakaf.

Sehubungan itu, objektif kajian ini adalah untuk meneliti secara terperinci model pelaksanaan pembangunan tanah wakaf ini, pematuhan kepada undangundang dan peraturan, perekodan dan pendedahan dalam penyata kewangan. Hasil kajian ini amat signifikan untuk melihat keberkesanan kaedah pelaksanaan

18 Rohayati Hussin \& Rusnadewi Abdul Rashid, 'Isu-Isu Berkaitan Tanah Wakaf Halangan Kepada Institusi Wakaf Pendidikan Tinggi di Malaysia,' 9.

19 Nurul Azma Abu Bakar, Muhammad Nasri Md Hussain \& Abu Bakar Hamed, 'Kaedah Pembangunan Tanah Wakaf Oleh Majlis Agama Islam dan Adat Melayu Perak (MAIPK),' Journal of Islamic, Sosial, Economics and Development, vol. 2/4 (2017): 8-9.

20 Muhammad Abdurrahman Sadique, 'Development of Dormant Waqf Properties: Application of Traditional and Contemporary Modes of Financing,' IIUM Law Journal, vol. 18/1 (2010): 75-103.

21 Hydzulkifli Hashim Omar \& Asmak Ab Rahman, Pembiayaan Pembangunan Harta Wakaf Menggunakan Sukuk (Kuala Lumpur: Universiti Malaya, 2015), 104.

22 Rohayu Abdul Majid \& Rosli Said, 'Permasalahan Pengurusan Hartanah Wakaf di Malaysia,' International Surveying Research Journal, vol. 4/1 (2014): 1.

23 Hydzulkifli Hashim Omar \& Asmak Ab Rahman, Pembiayaan Pembangunan Harta Wakaf Menggunakan Sukuk (Kuala Lumpur: Universiti Malaya, 2015), 104. 
Pembangunan Tanah Wakaf Secara Penswastaan: Kajian Terhadap Projek Menara Imarah Wakaf oleh Majlis Agama Islam Wilayah Persekutuan

projek ini dan sama ada model ini boleh dijadikan rujukan oleh institusi yang menguruskan wakaf supaya pembangunan tanah wakaf dapat dibuat dengan cekap dan berkesan. Dapatan kajian boleh dijadikan asas oleh MAIWP untuk memantapkan pengurusan wakaf di Wilayah Persekutuan khususnya dan Malaysia amnya.

\section{KAJIAN LEPAS}

Malaysia mempunyai 4,488 hektar tanah wakaf yang terdiri daripada tanah wakaf am milik MAIN melibatkan Semenanjung Malaysia, Sabah dan Sarawak. ${ }^{24}$ Tanah wakaf am adalah lebih mudah untuk dimajukan kerana tidak tertakluk pada niat pewakaf jika dibandingkan dengan tanah wakaf khas seperti masjid dan surau. Wakaf memainkan peranan penting bagi memenuhi keperluan kebajikan umat Islam di Malaysia dan pembangunan ekonomi negara terutamanya dalam mengurangkan kadar kemiskinan menerusi agihan semula kekayaan, menyediakan perkhidmatan kesihatan, pelajaran, penubuhan pusat anak yatim, masjid dan tempat kediaman yang memerlukan. ${ }^{25}$ Pemegang amanah wakaf perlu mencari jalan untuk membangunkan harta wakaf selagi mana ia tidak melanggar syarat-syarat wakaf serta menjaga hasrat pewakaf agar dapat menjana ekonomi umat Islam. Beberapa kaedah boleh digunakan untuk tujuan memproduktifkan aset wakaf antaranya memberi sewa aset wakaf yang sedia ada kepada penyewa; melakukan aktiviti ekonomi pertanian dan penternakan di atas tanah wakaf dan membuat pembangunan di atas tapak wakaf. ${ }^{26}$

Terdapat bukti bahawa inisiatif yang dibuat oleh pihak swasta dengan pengalaman dalam bidang korporat dan profesional dapat membantu pihak berkuasa agama di negeri untuk membangunkan aset wakaf. ${ }^{27}$ Dari segi

24 Afiffudin Mohammed Noor, Rusnadevi Abdul Rashid, Rohayati Hussin \& Noor Inayah Yaakub, 'Aplikasi Konsep Pajakan dalam Pembangunan Tanah Wakaf di Negeri Kedah Darul Aman,' Muktamar Waqf Iklimi II (Nilai: Universiti Sains Islam Malaysia, 2015), 2.

25 Asmak Ab Rahman, 'Peranan Wakaf dalam Pembangunan Ekonomi Umat Islam dan Aplikasinya di Malaysia,' 133.

26 Hydzulkifli Hashim Omar, Azizi Abu Bakar, Mohd Sollehudin Shuib \& Mohd Kamal Azman Jusoh, 'Penggunaan Kaedah Bot dalam Usaha Membangunkan Tanah Wakaf Majoodsaw Pulau Pinang', The Islamic Endowment Seminar (Nilai, Universiti Sains Islam Malaysia (USIM), 2014), 5.

27 Hajah Mustafa Mohd Hanefah, Abdullah Jalil, Asharaf Mohd Ramli, Hisham Sabri, Norhaziah Nawai \& Syahidawati Shahwan, 'Financing The Development of Waqf Property: The Experience of Malaysia and Singapore,' The Journal of Muamalat and Islamic Finance Research, vol. 8/1 (2011): 102. 
praktikal, kaedah Built, Operate dan Transfer (BOT) adalah antara kaedah yang berjaya diaplikasikan di Malaysia dalam membangunkan hartanah wakaf seperti yang dilaksanakan oleh MAIWP dalam membangunkan Menara Imarah Wakaf. ${ }^{28}$ Majlis Agama Islam Negeri Perak membangunkan tanah wakaf mereka melalui beberapa kaedah pembangunan yang telah dan akan dijalankan iaitu Bina-Pajak-Kendali-Senggara-Milik, Bina-Milik, BinaSelenggara-Kendali-Milik, Bina-Pajak-Selenggara-Milik dan Usaha sama. ${ }^{29}$

Kaedah BOT telah digunakan oleh Majlis Agama Islam Negeri Pulau Pinang (MAINPP) untuk membangunkan kompleks pejabat 21 tingkat di atas tanah wakaf Majoodsaw, Timur Laut George Town, Pulau Pinang. ${ }^{30}$ Mengikut penulis, sebagai balasan kepada pemaju, bangunan yang telah siap dibina akan diberikan tempoh konsesi selama tempoh 99 tahun dan MAINPP mendapat pulangan berupa dua tingkat, iaitu aras tujuh dan lapan bangunan wakaf Majoodsaw secara percuma serta 10 lot parkir kereta untuk tujuan sewaan. Menurut penulis lagi, kaedah pembangunan tanah ini sesuai dijadikan sebagai model pembangunan harta wakaf yang terletak di kawasan strategik bersama sedikit perubahan terhadap tempoh pajakan supaya lebih singkat. Selain kaedah BOT, terdapat juga pembangunan yang menggunakan kaedah usaha sama iaitu antara Majlis Agama Islam Negeri Pulau Pinang dan Uda Holdings Bhd dalam pembangunan projek perumahan tanah wakaf Setee Aishah. ${ }^{31}$ Dengan adanya usaha seperti ini, penggunaan tanah wakaf dapat dioptimumkan serta memberi manfaat kepada penerima manfaat secara khusus dan juga masyarakat secara umum.

Kebanyakan kajian terhadap wakaf tidak menyentuh mengenai isu perakaunan terhadap wakaf dan pelaporan transaksi wakaf. Tambahan

28 Nurul Azma Abu Bakar, Muhammad Nasri Md Hussain \& Abu Bakar Hamed, 'Kaedah Pembangunan Tanah Wakaf Oleh Majlis Agama Islam dan Adat Melayu Perak (MAIPK),' 3.

29 Nurul Azma Abu Bakar, Muhammad Nasri Md Hussain \& Abu Bakar Hamed, 'Kaedah Pembangunan Tanah Wakaf Oleh Majlis Agama Islam dan Adat Melayu Perak (MAIPK),' 6.

30 Hydzulkifli Hashim Omar, Azizi Abu Bakar, Mohd Sollehudin Shuib \& Mohd Kamal Azman Jusoh, 'Penggunaan Kaedah Bot dalam Usaha Membangunkan Tanah Wakaf Majoodsaw Pulau Pinang', The Islamic Endowment Seminar (Nilai, Universiti Sains Islam Malaysia (USIM), 2014), 10.

31 Hydzulkifli Hashim \& Asmak Abdul Rahman, 'Pengurusan Pembangunan Harta Wakaf: Pengalaman Majlis Agama Islam Negeri Pulau Pinang,' International Journal of Management Studies, vol. 19/2 (2012): 109. 
Pembangunan Tanah Wakaf Secara Penswastaan: Kajian Terhadap Projek Menara Imarah Wakaf oleh Majlis Agama Islam Wilayah Persekutuan

lagi, ketiadaan piawaian pelaporan yang khusus untuk wakaf, mutawalli $\bar{\imath}^{32}$ khususnya di Malaysia perlu menerima pakai kerangka pelaporan kewangan yang diguna pakai oleh organisasi yang berorientasikan keuntungan. ${ }^{33}$ Penulis juga mengenal pasti praktis perakaunan MAIN dan kualiti pelaporannya merupakan alat ukuran yang menggambarkan tahap akauntabiliti. Kajian awal menunjukkan walaupun asas akauntabiliti kelihatan wujud dalam praktis pengurusan, perakaunan dan pelaporan bagi wakaf entiti yang dikaji namun penambahbaikan yang signifikan kekal penting untuk memastikan akauntabiliti dapat dipertingkatkan secara berterusan.

Data menunjukkan perbezaan dalam model tadbir urus boleh memberi impak secara langsung terhadap amalan perakaunan dan pelaporan kewangan bagi institusi wakaf, zakat dan baitulmal berikutan tiada piawaian perakaunan yang sama digunakan sebagai asas penyediaan laporan kewangan. ${ }^{34}$ Kajian juga mendapati bahawa tidak semua harta yang diwakafkan telah didedahkan dalam penyata kewangan tahunan agensi. Kepentingan maklumat naratif untuk menerangkan dan memberi justifikasi angka-angka perakaunan atau maklumat perakaunan terutamanya berkaitan dengan wakaf. ${ }^{35}$ Responden ingin mengetahui perkembangan projek pembangunan dan pelaburan harta wakaf serta kedudukan institusi sebagai mutawalli berkaitan perkara ini. Sebagai pemegang amanah, institusi wakaf bertanggungjawab kepada Allah

32 Mutawallī ialah penjaga harta wakaf atau nazir yang dilantik. Menurut Wahbah al-Zuhaylī apabila jawatan nazir diserah kepadanya, ia hendaklah menjaga harta wakaf dan memajukannya, menyewakannya, menanamnya dan mempertahankan haknya, mendapatkan hasil daripada sewa atau tanaman dan buah-buahannya, mengagihkannya kepada mereka yang berhak dan menjaga harta yang menjadi modal asal serta hasil keluarannya dengan cara yang lebih berhati-hati.

33 Hairul Suhaimi Nahar Hisham Yaacob, 'Accountability in the Sacred Context: The Case of Management, Accounting and Reporting of A Malaysian Cash Awqaf Institution,' Journal of Islamic Accounting and Business Research, vol. 2/2 (2011): 94.

34 Abdullah Abdul Ghani, Rohami Shafie, Md. Suhaimi Md. Salleh, Faisol Ilham, Muhamad Hanif Abdul Kadir, Mohamad Sharofi Ismail, Fathilatul Zakimi Abdul Hamid, Nasri Naimi \& Zaleha Othman, 'Isu-isu dalam Pengurusan dan Pelaporan Wakaf, Zakat dan Baitulmal bagi Institusi Wakaf, Zakat dan Baitulmal di Malaysia,' IPN Journal of Research and Practice in Public Sector Accounting and Management, vol. 7 (2017): 46.

35 Mohd Fairuz Md Salleh, Azlina Ahmad, Norida Basnan, Azizah Harun, Hairunnizam Wahid \& Ainol Basirah Abdul Wahab, 'Disclosure of Non-Financial Information in Discharging Accountability of Waqf Trustee,' IPN Journal of Research and Practice in Public Sector Accounting and Management, vol. 7 (2017): 23. 
SWT dan pewakaf serta pihak yang berkepentingan secara khususnya dan kepada masyarakat secara amnya. Tanggungjawab akauntabiliti yang lebih besar dapat dilaksanakan melalui medium pelaporan seperti laporan kewangan yang mendedahkan maklumat yang berkaitan secara komprehensif termasuk maklumat kewangan.

Isu akauntabiliti terutama berkaitan wakaf dan zakat ini menunjukkan betapa perlunya satu garis panduan khusus bagi pelaporan oleh institusi wakaf, zakat dan baitulmal bagi memastikan pelaksanaan dan penzahiran akauntabiliti mereka kepada Allah SWT. ${ }^{36}$ Tahap akauntabiliti yang tertinggi secara umumnya bermaksud maklumat kuantitatif dan kualitatif dilaporkan dan maklumat berkaitan hasil dan keputusan juga didedahkan. ${ }^{37}$ Penulis berpendapat ianya sangat penting kerana pewakaf dan pihak yang berkepentingan perlu dimaklumkan tujuan dana digunakan dan bagaimana tersebut digunakan bagi memberikan manfaat yang optimum.

\section{METODOLOGI KAJIAN}

Secara keseluruhannya, kajian ini menggunakan kaedah kualitatif. Kaedah ini menggunakan data primer dan data sekunder yang diperoleh melalui kajian lapangan dan kajian kepustakaan. Data primer diperoleh daripada temu bual secara semi struktur dengan pegawai MAIWP yang terlibat dengan pembangunan harta wakaf dan penyediaan penyata kewangan berkaitan wakaf. Proses temu bual ini mengambil masa antara 40 hingga 50 minit untuk setiap responden dan soalan yang dikemukakan berdasarkan objektif kajian serta mengikut bidang tugas masing-masing seperti Jadual 1.

36 Mohd Fairuz Md Salleh, Norida Basnan, Azlina Ahmad, Azizah Harun, Muhammad Arzim Naim \& Hairunnizam Wahid, 'Cadangan Item Pendedahan Bagi Pelaporan Institusi Wakaf, Zakat dan Baitulmal,' IPN Journal of Research and Practice in Public Sector Accounting and Management, vol. 6 (2016): 27.

37 Maliah Sulaiman, Muslim Har Sani Mohamad, Hafiz Majdi Abdul Rashid, Ahmad Zamri Osman, Siti Alawiah Siraj \& Ibrahim Nunu, 'Accounting And Accountability of Waqf, Zakat and Baitul Mal in Malaysia', IPN Journal of Research and Practice in Public Sector Accounting and Management, vol. 6 (2016): 8. 
Pembangunan Tanah Wakaf Secara Penswastaan: Kajian Terhadap Projek Menara Imarah Wakaf oleh Majlis Agama Islam Wilayah Persekutuan

Jadual 1: Struktur Soalan Kajian Kepada Responden

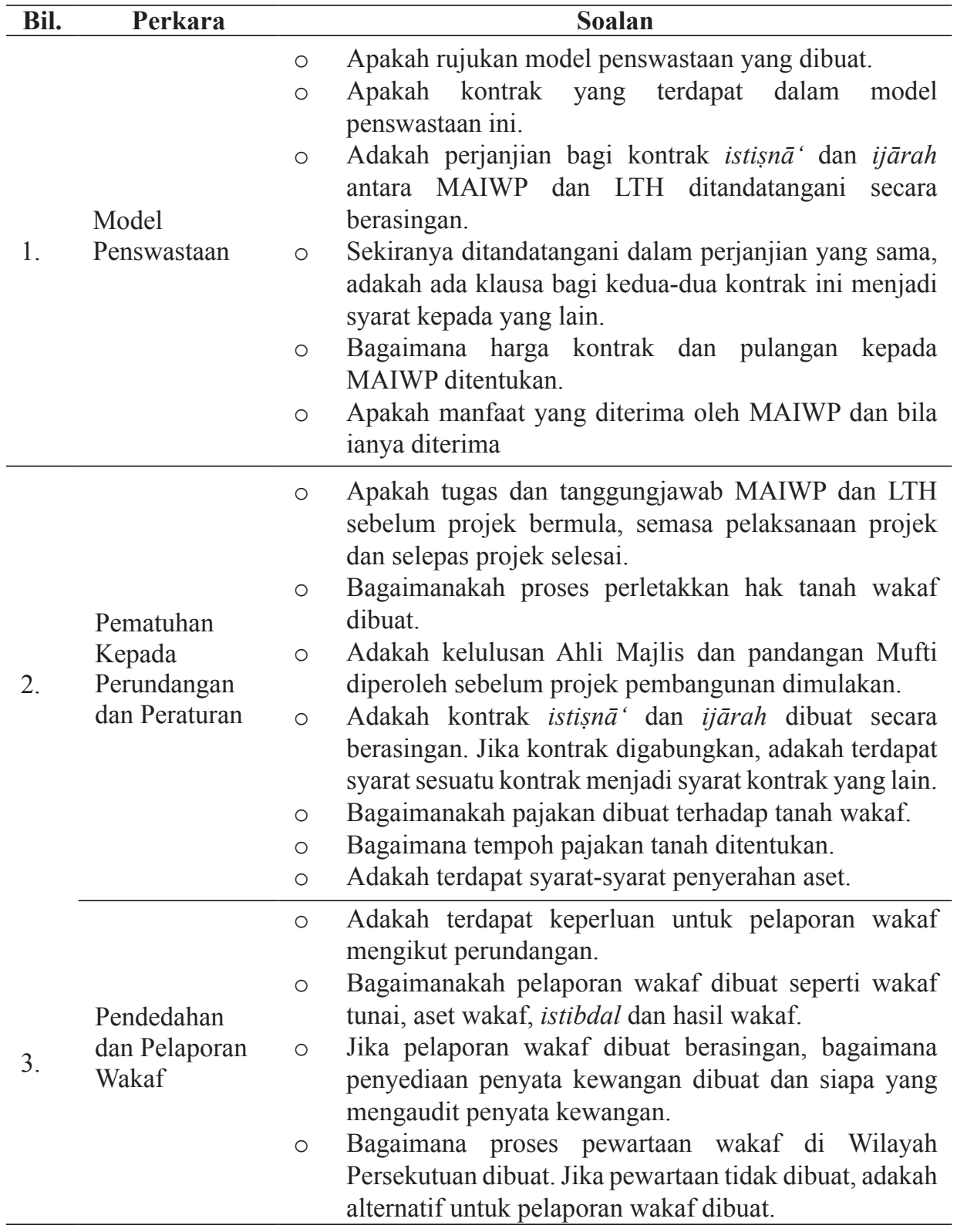

Sumber: Maklumat kajian

Temu bual ini dijalankan pada 14 Mac dan 7 Ogos 2018 di pejabat MAIWP dan pada 19 September 2018 di Ibu Pejabat Lembaga Tabung Haji, Kuala 
Lumpur. Maklumat daripada temu bual telah direkodkan untuk memudahkan proses penganalisaan. Kaedah ini juga menghasilkan data primer yang tidak boleh diragui kesahihannya kerana pegawai yang ditemu bual merupakan pegawai yang berpengalaman dalam bidang masing-masing seperti di Jadual 2.

Jadual 2: Profil Responden

\begin{tabular}{|c|c|c|c|}
\hline Bil. & Responden & Agensi & Jawatan \\
\hline 1. & $\begin{array}{l}\text { Ir. Abdul Karim bin } \\
\text { Mohamed }\end{array}$ & MAIWP & $\begin{array}{l}\text { Pengurus Bahagian } \\
\text { Pembangunan dan Pelaburan }\end{array}$ \\
\hline 2. & Aniza binti Abdullah & MAIWP & Pengurus Unit Audit Dalam \\
\hline 3. & $\begin{array}{l}\text { Wan Mohd Sanusi bin } \\
\text { Mohd Noor }\end{array}$ & MAIWP & $\begin{array}{l}\text { Timbalan Pengurus Unit } \\
\text { Undang-undang }\end{array}$ \\
\hline 4. & Hasmiza binti Hashim & MAIWP & $\begin{array}{l}\text { Timbalan Pengurus Bahagian } \\
\text { Kewangan }\end{array}$ \\
\hline 5. & $\begin{array}{l}\text { Norsaliza binti Mohamad } \\
\text { Ali }\end{array}$ & MAIWP & $\begin{array}{l}\text { Penolong Pengurus Bahagian } \\
\text { Kewangan }\end{array}$ \\
\hline 6. & $\begin{array}{l}\text { Radin Adi Hilmi bin Radin } \\
\text { Shamsudin }\end{array}$ & LTH & $\begin{array}{l}\text { Pengurusan Kanan (Pelaburan } \\
\text { Hartanah) }\end{array}$ \\
\hline
\end{tabular}

Sumber: Maklumat kajian

Kaedah pengumpulan data juga disokong oleh kaedah lain bagi mendapatkan maklumat penting yang akan melengkapkan dapatan kajian. Bagi mendapatkan data sekunder, pengumpulan data adalah secara kajian perpustakaan dan laman sesawang. Penelitian dibuat terhadap akta, enakmen, standard atau piawaian yang berkaitan untuk menghasilkan dapatan kajian. Bahan seperti artikel jurnal, kertas kerja, kertas prosiding dan laporan tahunan dijadikan rujukan untuk menyokong kajian ini. Kajian dianalisis secara deskriptif iaitu dengan menghuraikan dapatan kajian selaras dengan objektif dan permasalahan kajian dengan terperinci.

\section{HASIL KAJIAN}

Pengurusan dan pentadbiran wakaf diletakkan di bawah Majlis Agama Islam setiap negeri dan Majlis Agama Islam Negeri (MAIN) merupakan pemegang amanah tunggal terhadap semua harta wakaf di Malaysia. Di Wilayah Persekutuan, MAIWP telah diberi mandat untuk mengurus harta wakaf berdasarkan Seksyen 61 hingga 68, Akta Pentadbiran Undang-undang Islam 
(Wilayah-wilayah Persekutuan) 1993 (Akta 505). ${ }^{38}$ Sebagai pemegang amanah tunggal, MAIWP bertanggungjawab terhadap semua aset wakaf yang terdapat di Wilayah Persekutuan Kuala Lumpur, Labuan dan Putrajaya. Walaupun jumlah keluasan tanah yang terdapat di Wilayah Persekutuan Kuala Lumpur kecil iaitu 10.76 ekar (39 lot) tetapi tanah tersebut bernilai tinggi kerana kedudukannya yang strategik. Bagi tujuan pembangunan tanah wakaf di tersebut, MAIWP melaksanakan projek pembangunan tanah secara penswastaan, pembiayaan dana daripada kerajaan dan melalui proses istibdal. Pembangunan tanah wakaf secara penswastaan telah dilaksanakan di atas tanah di lot 168 dan 169 seluas 1.2 ekar di Jalan Perak, Kuala Lumpur memandangkan tanah tersebut berpotensi untuk memberi pulangan yang tinggi. Model pelaksanaan projek penswastaan ini adalah seperti di Rajah 1.

Rajah 1: Model Projek Penswastaan Pembinaan Menara Imarah Wakaf

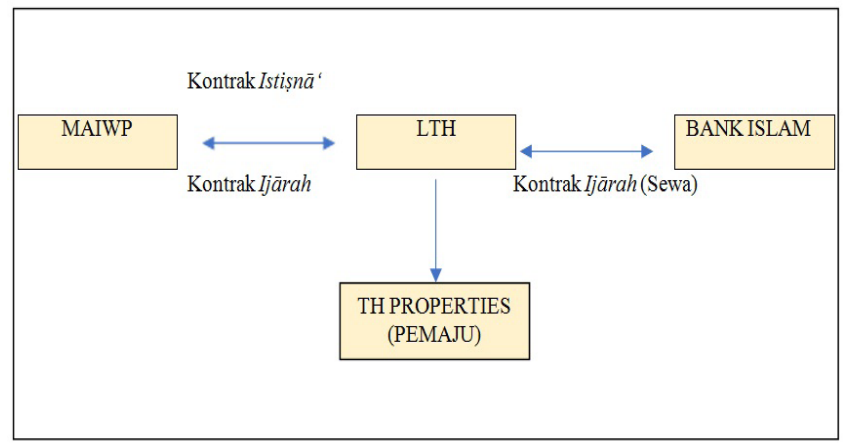

Sumber: Temu bual bersama Pegawai MAIWP 2018

Perjanjian pembangunan projek telah ditandatangani di antara MAIWP dan LTH secara istișna' ${ }^{\prime}$ pada tahun 2006. Kos pembinaan bangunan sejumlah RM151 juta dibiayai oleh LTH dan telah siap dibina pada tahun 2011. Bangunan yang telah siap dikenali sebagai Menara Imarah Wakaf telah disewakan sebahagian besarnya kepada Bank Islam Malaysia Berhad untuk tempoh yang tertentu. Projek ini memberikan hasil pajakan kepada MAIWP berjumlah RM56.60 juta dalam tempoh 25 tahun dan pemilikan bangunan akan diserahkan kepada MAIWP selepas tempoh tersebut. Selepas tamat tempoh pajakan, MAIWP akan memperoleh tanah berserta menara tersebut dengan nilai anggaran RM600 juta. ${ }^{39}$ Nilai tanah wakaf ini juga telah meningkat di

38 Akta Pentadbiran Undang-undang Islam (Wilayah-wilayah Persekutuan) 1993.

39 Azman Mat Noor \& Saidatolakma Mohd Yunus, 'Penggunaan Akad Build, Operate and Transfer Sebagai Cara Pembiayaan (Kewangan) dalam Membangunkan Tanah Wakaf Oleh Majlis Agama Islam Wilayah Persekutuan: Satu Analisis Mengikut Perspektif Syariah,' Jurnal Muamalat, vol. 4 (2011): 11. 
mana nilai tanah sebelum projek dilaksanakan ialah RM31.92 juta dan anggaran nilai pada tahun 2018 ialah RM197 juta. Maklumat terperinci mengenai projek ini adalah seperti di Jadual 3.

Jadual 3: Maklumat Projek Pembangunan Menara Imarah Wakaf

\begin{tabular}{ll}
\hline \multicolumn{1}{c}{ Perkara } & \multicolumn{1}{c}{ Maklumat } \\
\hline Perjanjian Penswastaan & MAIWP dan LTH \\
Tarikh Perjanjian & 11 Disember 2006 \\
Tarikh Mula Projek & 2007 \\
Tarikh Siap Projek & 2011 \\
Kos Projek & RM151 juta \\
Pemaju & TH Properties \\
No. Lot dan Luas Tanah Wakaf & Lot 168 \& 169, Keluasan 1.2 ekar \\
Lokasi Projek & Jalan Perak, Kuala Lumpur \\
Anggaran Nilai Tanah Pajakan & RM31.92 juta \\
Hasil Pajakan & RM56.60 juta \\
Tempoh Pajakan & 25 tahun \\
\hline
\end{tabular}

Sumber: Dokumen Perjanjian dan temu bual

Analisis telah dibuat terhadap pematuhan undang-undang dan peraturan dalam pelaksanaan projek penswastaan menggunakan tanah wakaf dan hasil kajian menunjukkan MAIWP telah mematuhi Kanun Tanah Negara, Akta Pentadbiran Undang-undang Islam (Wilayah-wilayah Persekutuan) 1993 (Akta 505) dan standard syariah oleh The Accounting and Auditing Organization for Islamic Financial Institution (AAOIFI) seperti di Jadual 4. 
Jadual 4: Pematuhan Terhadap Perundangan dan Peraturan

\begin{tabular}{l}
\hline Bil. Undang-Undang/Peraturan \\
\hline \\
i) Akta Pentadbiran Undang-undang Islam \\
(Wilayah-wilayah Persekutuan) 1993 \\
(Akta 505), Seksyen 62 Perletakkan Hak \\
(1) Semua harta yang tertakluk kepada \\
peruntukan-peruntukan seksyen \\
61 dan terletak di dalam Wilayah- \\
Wilayah Persekutuan, hendaklah, \\
tanpa apa-apa pemindahhakan, \\
penyerahhakan atau pemindahmilikan \\
jua pun, dan, dalam hal harta tak alih, \\
sebaik sahaja didaftarkan di bawah \\
undang-undang bertulis yang relevan \\
yang berhubungan dengan tanah, \\
terletakhak pada Majlis, bagi maksud- \\
maksud amanah, wakaf atau nazr 'am \\
yang menyentuh harta itu.
\end{tabular}

ii) Seksyen 416C, Kanun Tanah Negara yang berkaitan dengan kaedah pendaftaran tanah wakaf melalui perletakkan hak berkanun.

Seksyen 33 Akta 505, Mufti hendaklah membantu dan menasihati Yang diPertuan Agong berkenaan dengan semua perkara Hukum Syarak, dan dalam semua perkara sedemikian hendaklah menjadi pihak berkuasa utama di Wilayah-Wilayah Persekutuan selepas Yang di-Pertuan Agong, kecuali jika diperuntukkan 2. selainnya dalam Akta ini.
Peletakkan hak (vesting order) telah dikeluarkan oleh Mahkamah Tinggi Kuala Lumpur pada 18 September 1991

MAIWP telah mendapat pandangan Mufti Wilayah Persekutuan pada tahun 2005 yang menyatakan harus bagi pihak berkuasa yang menerima tawaran daripada manamana pihak untuk membangunkan tanah dengan syarat:

- Tawaran tersebut memberi faedah dan keuntungan yang lebih kepada pihak yang menerima wakaf daripada wakaf asal; dan

- Perlu ada gantian yang berkekalan juga di samping unit-unit bangunan yang ditawarkan. 


\begin{tabular}{ll}
\hline Bil. & \multicolumn{3}{c}{ Undang-Undang/Peraturan } \\
\hline & Seksyen 7(2) (a) Akta 505, Majlis \\
hendaklah mempunyai kuasa untuk \\
menjalankan segala kegiatan, yang tidak \\
akan melibatkan apa-apa unsur yang tidak \\
dibenarkan oleh agama Islam, khususnya \\
memajukan perusahaan komersil dan \\
perindustrian, yang perjalanannya ternyata \\
kepada Majlis adalah perlu, berfaedah \\
atau menyenangkan bagi atau berkaitan \\
dengan penunaian kewajipannya.
\end{tabular}

Para 7/2/1 Shari'a Standard No. 33 Waqf

4. (AAOIFI) menyatakan pembangunan tanah wakaf adalah dibenarkan mengikut kontrak istiṣnā' secara kontrak BOT.

Gabungan akad istiṣna ' dan ijārah dalam BOT sah dipraktikkan kerana penggunaan

5. kedua-dua akad telahpun dipersetujui oleh ulama fiqh kontemporari di persidangan Majma Fiqhi di Dubai 2009.

Persidangan Majma Fiqhi di Dubai 2009 menetapkan syarat kontrak mestilah

6. bersih daripada unsur-unsur riba dan bebas daripada elemen yang bertentangan dengan tujuan sebenar akad

i) Seksyen 5 Kanun Tanah Negara mendefinisikan perkataan tuan punya sebagai mana-mana orang atau badan yang buat masa itu didaftarkan sebagai tuan punya mana-mana tanah beri milik.

ii) Para 6/3 Shari'a Standard No. 33 Waqf (AAOIFI) menyatakan antara bentuk

7. pajakan yang dibenarkan adalah berkaitan pembangunan wakaf.

iii) Fuqaha juga mengharuskan pelaksanaan pajakan terhadap sesuatu tanah wakaf dalam dua keadaan iaitu apabila berlaku keperluan yang mendesak atau darurat dan menjaga kepentingan harta wakaf.
Projek penswastaan yang dijalankan oleh MAIWP adalah mengikut kontrak istișna $\bar{a}^{\prime}$ secara Built, Operate \& Transfer (BOT).

Kontrak ditandatangani menggabungkan akad istiṣna $\bar{a}^{\prime}$ dan ijārah

Pembiayaan daripada LTH tidak mempunyai unsur gharar, maysīr dan riba.

Pajakan ke atas tanah wakaf dibenarkan. Pajakan hanya boleh dilakukan selepas tanah wakaf didaftarkan atas nama MAIWP. Ini adalah kerana pajakan atau pajakan kecil hanya boleh diberikan terhadap tanah yang diberi milik dan mempunyai hak milik sahaja selaras dengan Seksyen 5, Kanun Tanah Negara. 
Pembangunan Tanah Wakaf Secara Penswastaan: Kajian Terhadap Projek

Menara Imarah Wakaf oleh Majlis Agama Islam Wilayah Persekutuan

\begin{tabular}{lcc}
\hline Bil. & \multicolumn{1}{c}{ Undang-Undang/Peraturan } & Dapatan Kajian \\
\hline & i) Mengikut Seksyen 221 Kanun Tanah & Tempoh pajakan 25 tahun adalah \\
Negara, tempoh pajakan perlu melebihi 3 & mematuhi Kanun Tanah Negara. \\
tahun tetapi tidak boleh melebihi 99 tahun & \\
bagi maksud pajakan seluruh tanah dan 30 & \\
tahun bagi pajakan sebahagian tanah. & \\
8. & ii) Para 6/1 Shari'a Standard No. 33 Waqf \\
(AAOIFI) menyatakan tempoh pajakan & \\
yang panjang bukan amalan biasa bagi \\
aset wakafkecuali dalam keadaan tertentu. \\
Para 7/2/2 Shari'a Standard No. 33 Waqf \\
(AAOIFI) menetapkan pemilikan aset & akhir tempoh pajakan. \\
wakaf perlu diserahkan selepas tempoh & \\
pajakan tamat. &
\end{tabular}

Sumber: Dapatan kajian

Berdasarkan Seksyen 62 Akta 505, semua harta yang tertakluk kepada peruntukan-peruntukan seksyen 61 iaitu wakaf dan nazr dan terletak di dalam Wilayah-Wilayah Persekutuan, hendaklah, tanpa apa-apa pemindahhakan, penyerahhakan atau pemindahmilikan dan dalam hal harta tak alih, sebaik sahaja didaftarkan di bawah undang-undang bertulis yang relevan yang berhubungan dengan tanah, terletakhak pada Majlis. ${ }^{40}$ Projek ini menggunakan tanah wakaf milik seorang saudagar kain dari India iaitu Allahyarham Ahmad Dawjee Dadabhoy. Harta beliau telah diserahkan kepada MAIWP melalui peletakkan hak (vesting order) yang dikeluarkan oleh Mahkamah Tinggi Kuala Lumpur pada 18 September $1991 .{ }^{41}$ Perkara ini juga selaras dengan Seksyen 416C, Kanun Tanah Negara yang berkaitan dengan kaedah pendaftaran tanah wakaf melalui perletakkan hak berkanun.

Permasalahan untuk memilih kaedah yang paling memenuhi syariah bagi membangunkan harta wakaf boleh diselesaikan dengan melibatkan Jabatan Mufti dan fatwa. ${ }^{42}$ Projek pembangunan ini telah merujuk kepada pandangan Mufti Wilayah Persekutuan pada tahun 2005 yang menyatakan bahawa harus

$40 \quad$ Akta Pentadbiran Undang-undang Islam (Wilayah-wilayah Persekutuan) 1993.

${ }_{41}$ Majlis Agama Islam Wilayah Persekutuan, Laporan Tahunan (Kuala Lumpur: MAIWP, 2007).

42 Hajah Mustafa Mohd Hanefah, Abdullah Jalil, Asharaf Mohd Ramli, Hisham Sabri, Norhaziah Nawai \& Syahidawati Shahwan, 'Financing The Development of Waqf Property: The Experience of Malaysia and Singapore,' 100. 
bagi pihak berkuasa yang menerima tawaran daripada mana-mana pihak untuk membangunkan tanah dengan syarat tawaran tersebut memberi faedah dan keuntungan yang lebih kepada pihak yang menerima wakaf daripada wakaf asal serta perlu ada gantian yang berkekalan juga di samping unit-unit bangunan yang ditawarkan. Perkara ini juga selaras dengan Jawatankuasa Fatwa Kali Keempat pada tahun 1982 yang bersetuju wakaf gantian dengan maksud menukar harta-harta wakaf dengan harta-harta yang lain melalui jualan atau belian atau sebagainya dengan tujuan mengekalkan harta wakaf adalah juga diharuskan mengikut takliq pendapat Imam Abu Hanifah. ${ }^{43}$

Projek penswastaan yang dijalankan oleh MAIWP adalah secara Built, Operate \& Transfer (BOT). Pembiayaan menggunakan kaedah BOT merupakan suatu perjanjian yang dibuat antara unit surplus (institusi kewangan dan perbankan Islam) dengan unit defisit (institusi wakaf) untuk pembangunan projek pembinaan. ${ }^{44}$ Menerusi kaedah ini, MAIWP memberi pajakan tanah wakaf kepada LTH secara kontrak istișna ${ }^{\prime}$ untuk membangunkan projek bagi tempoh tertentu dengan pembiayaan oleh LTH. Perkara ini selaras dengan para 7/2/1 Shari'a Standard No. 33 Waqf (AAOIFI) menyatakan pembangunan tanah wakaf adalah dibenarkan mengikut kontrak istișna $\bar{a}^{\prime}$ secara BOT. Selepas projek selesai dijalankan, LTH akan menyewa daripada MAIWP dan menjalankan operasinya selama 25 tahun di bawah akad ijārah. Klausa mengenai istișna $\bar{a}^{\prime}$ dan ijärah tersebut dinyatakan secara berasingan dalam perjanjian yang sama yang ditandatangani antara MAIWP dan LTH pada tahun 2006. LTH menjalankan operasi dan menguruskan bangunan tersebut bagi tempoh 25 tahun dengan menyewakan kepada BIMB dan pihak lain. LTH menanggung kos penyelenggaraan bagi memastikan bangunan sentiasa dalam keadaan yang baik. Setelah tamat tempoh pengurusan, LTH akan menyerahkan semula bangunan tersebut berserta tanah kepada MAIWP.

MAIWP telah menerima hasil pajakan secara bulanan daripada LTH selepas bangunan tersebut siap pada tahun 2011 sehingga 2036. Rekod yang diselenggarakan oleh MAIWP adalah Rekod Daftar Sewa dan Rekod Nilaian Tanah. Jadual 5 menunjukkan dapatan berhubung pelaporan dan pendedahan wakaf bagi projek ini.

43 Jabatan Kemajuan Islam Malaysia, 'Kompilasi Pandangan Hukum, Muzakarah Jawatankuasa Fatwa Majlis Kebangsaan Bagi Hal Ehwal Ugama Islam,' 55, https:// www.islam.gov.my, dicapai pada 15 April 2018.

44 Hydzulkifli Hashim Omar \& Asmak Ab Rahman, Pembiayaan Pembangunan Harta Wakaf Menggunakan Sukuk (Kuala Lumpur: Universiti Malaya, 2015), 21. 
Pembangunan Tanah Wakaf Secara Penswastaan: Kajian Terhadap Projek

Menara Imarah Wakaf oleh Majlis Agama Islam Wilayah Persekutuan

Jadual 5: Pendedahan dan Pelaporan Wakaf

\begin{tabular}{l}
\hline Rijukan Undang-Undang dan \\
Peraturan \\
\hline i) Mengikut Seksyen 67 Akta 505, \\
MAIWP perlu menyediakan akaun dan \\
laporan tahunan mengikut peruntukan \\
Akta Badan Berkanun (Akaun dan \\
Laporan Tahunan) 1980. \\
1. \\
ii) Para 6/1 Shari’a Standard No. 33 \\
Waqf (AAOIFI) menetapkan penyediaan \\
akaun wakaf dan mengemukakan \\
penyata kewangan dan laporan kepada \\
pihak yang berkuasa.
\end{tabular}

Seksyen 68 Akta 505, Harta Wakaf dan Nazr

Majlis dengan seberapa segera yang mungkin selepas 31 Disember tiap-

2. tiap tahun hendaklah menyediakan, mengeluarkan dan menyiarkan dalam warta satu senarai harta, pelaburan dan aset yang terletak hak pada Majlis tertakluk kepada mana-mana amanah, wakaf atau nazr dan tidak menjadi sebahagian daripada kumpulan wang.
Hasil pajakan tidak diakaunkan dalam penyata kewangan tahunan MAIWP kerana MAIWP telah menyediakan penyata kewangan berasingan untuk mengakaunkan terimaan wakaf daripada Ahmad Dawjee Dadabhoy yang dikenali sebagai Wakaf Ahmad Dawjee Dadabhoy.

Penyata kewangan wakaf tersebut bagi tahun kewangan 2006 sehingga terkini selesai disediakan.

MAIWP belum menyenaraikan dan mewartakan semua harta wakafnya seperti yang dikehendaki oleh Seksyen 68 Harta Wakaf dan Nazr, Akta 505. Namun begitu, bagi tujuan pendedahan kepada pihak berkepentingan, MAIWP telah menyediakan pelaporan dan prestasi wakaf tersebut di dalam Laporan Tahunan MAIWP yang dibentang di Parlimen dan boleh diakses oleh masyarakat.

Sumber: Dapatan kajian

Berdasarkan temu bual, hasil pajakan tersebut tidak diakaunkan dalam penyata kewangan tahunan MAIWP kerana MAIWP menyediakan penyata kewangan berasingan untuk mengakaunkan terimaan wakaf daripada Ahmad Dawjee Dadabhoy yang dikenali sebagai Wakaf Ahmad Dawjee Dadabhoy. Penyediaan penyata kewangan Wakaf Ahmad Dawjee Dadabhoy disediakan kerana tanggungjawab MAIWP sebagai pemegang amanah walaupun tiada peruntukan dalam Akta 505 untuk menyediakan akaun wakaf.

Mengikut Seksyen 68 Akta 505, Majlis dengan seberapa segera yang mungkin selepas 31 Disember tiap-tiap tahun hendaklah menyediakan, mengeluarkan dan menyiarkan dalam warta satu senarai harta, pelaburan dan aset yang terletak hak pada Majlis tertakluk kepada mana-mana amanah, 
wakaf atau nazr dan tidak menjadi sebahagian daripada kumpulan wang. ${ }^{45}$ Berdasarkan temu bual, MAIWP belum menyenaraikan dan mewartakan semua harta wakafnya seperti yang dikehendaki oleh Seksyen 68 Harta Wakaf dan Nazr, Akta 505. Namun begitu, bagi tujuan pendedahan kepada pihak berkepentingan, MAIWP telah menyediakan pelaporan dan prestasi wakaf tersebut di dalam Laporan Tahunan MAIWP yang dibentang di Parlimen dan boleh diakses oleh masyarakat.

\section{PERBINCANGAN DAN IMPLIKASI DASAR}

Akad BOT sesuai digunakan dalam membangunkan harta wakaf dan ia merupakan mekanisme yang tidak bertentangan dengan Syariah. ${ }^{46}$ Pengkaji berpendapat kontrak BOT boleh dijadikan sebagai alternatifbagi menyelesaikan masalah kekurangan sumber kewangan dalam memajukan harta wakaf. Gabungan akad istișnā' dan ijārah dalam BOT membuktikan ianya sah dipraktikkan kerana penggunaan kedua-dua akad telah pun dipersetujui oleh ulama fiqh kontemporari di persidangan Majma Fiqhi di Dubai 2009 tertakluk kepada syarat-syarat tertentu. ${ }^{47}$ Mengikut penulis lagi, syarat yang ditetapkan ialah semua perkara yang ditegah oleh syariah tidak boleh ada dalam gabungan akad; konsep gabungan akad mestilah tidak digunakan sebagai cara untuk melakukan riba; gabungan akad tidak boleh dijadikan pengecualian untuk melakukan riba; dan gabungan akad mestilah bebas daripada elemen yang bertentangan dengan tujuan sebenar akad. Secara kesimpulannya, tujuan akad dalam BOT ini tidak bertentangan dengan Syariah iaitu memelihara harta wakaf yang dilaksanakan menggabungkan istiṣna' 'dan ijārah. Selain itu, ia mestilah bersih daripada unsur-unsur gharar, maysīr dan riba.

Dalam aspek pembangunan projek secara BOT, pemaju perlu mempunyai sumber kewangan yang mencukupi untuk membiayai kos projek. Sekiranya pemaju tidak mempunyai sumber yang mencukupi dikhuatiri pemaju akan membuat pinjaman yang berasaskan riba dan tidak patuh Syariah. Pinjaman

45 Seksyen 68 Harta Wakaf dan Nazr, Akta Pentadbiran Undang-undang Islam (Wilayah-wilayah Persekutuan) 1993.

46 Azman Mat Noor \& Saidatolakma Mohd Yunus, 'Penggunaan Akad Build, Operate and Transfer Sebagai Cara Pembiayaan (Kewangan) dalam Membangunkan Tanah Wakaf Oleh Majlis Agama Islam Wilayah Persekutuan: Satu Analisis Mengikut Perspektif Syariah,' 23.

47 Azman Mat Noor \& Saidatolakma Mohd Yunus, 'Penggunaan Akad Build, Operate and Transfer Sebagai Cara Pembiayaan (Kewangan) dalam Membangunkan Tanah Wakaf Oleh Majlis Agama Islam Wilayah Persekutuan: Satu Analisis Mengikut Perspektif Syariah,' 24. 
sebegini tidak dibenarkan oleh Islam lebih-lebih lagi pembangunan itu bertujuan untuk memajukan harta wakaf. ${ }^{48}$ Bagaimanapun, bagi projek pembangunan tanah wakaf ini, LTH mempunyai sumber kewangan yang mencukupi untuk membiayai keseluruhan kos pembangunan projek. Secara jelasnya, projek penswastaan secara BOT ini bersih dari unsur-unsur gharar, maysìr dan riba.

Fuqaha mengharuskan pelaksanaan pajakan terhadap sesuatu tanah wakaf dalam dua keadaan iaitu apabila berlaku keperluan yang mendesak atau darurat dan menjaga kepentingan harta wakaf serta kemaslahatan penyewa harta wakaf walaupun bukan dalam keadaan yang mendesak. ${ }^{49}$ Mengikut Seksyen 221, Kanun Tanah Negara, tempoh pajakan perlu melebihi 3 tahun tetapi tidak boleh melebihi 99 tahun bagi maksud pajakan seluruh tanah dan 30 tahun bagi pajakan sebahagian tanah. Pihak MAIN perlu memastikan tanah-tanah wakaf yang hendak dipajak sudah melalui proses pendaftaran hak milik. ${ }^{50}$ Tanah wakaf yang masih di bawah nama pemilik asal tidak boleh dipajakkan oleh MAIN. Seksyen 5, Kanun Tanah Negara (KTN) mendefinisikan tuan punya sebagai mana-mana orang atau badan yang buat masa itu didaftarkan sebagai tuan punya mana-mana tanah beri milik. ${ }^{51}$

Pemilikan bangunan Menara Imarah Wakaf akan diserahkan pada akhir tahun tempoh pajakan 25 tahun. Walaupun pemilikan bangunan tersebut akan berkuat kuasa mengikut perjanjian yang ditandatangani oleh kedua-dua pihak namun pihak MAIWP perlu mendaftar bangunan tersebut sebagai harta wakaf yang baru bagi memenuhi rukun-rukun wakaf. Ini berdasarkan muzakarah Jawatankuasa Fatwa Majlis Kebangsaan Malaysia kali ke 77 yang bersidang pada tahun 2007 yang memutuskan mengenai status bangunan yang telah disiap dibina di atas tanah wakaf seperti berikut:

a) Bangunan yang telah siap dibina atas tanah wakaf tidak menjadi wakaf secara automatik.

b) Bangunan tersebut perlu didaftarkan sebagai harta wakaf yang baru dan perlu memenuhi rukun-rukun wakaf dan enakmen negeri.

48 Azman Mat Noor \& Saidatolakma Mohd Yunus, 'Penggunaan Akad Build, Operate and Transfer Sebagai Cara Pembiayaan (Kewangan) dalam Membangunkan Tanah Wakaf Oleh Majlis Agama Islam Wilayah Persekutuan: Satu Analisis Mengikut Perspektif Syariah,' 15.

49 Afiffudin Mohammed Noor, Rusnadevi Abdul Rashid, Rohayati Hussin \& Noor Inayah Yaakub, 'Aplikasi Konsep Pajakan dalam Pembangunan Tanah Wakaf di Negeri Kedah Darul Aman,' 3-4.

50 Seksyen 221, Kanun Tanah Negara.

51 Seksyen 5, Kanun Tanah Negara. 
Bagi penyediaan penyata kewangan di MAIWP, isu yang berbangkit ialah terdapat harta wakaf yang dilaporkan dalam penyata kewangan dan juga harta wakaf yang dilaporkan secara berasingan iaitu Wakaf Ahmad Dawjee Dadabhoy. Pelaporan harta wakaf oleh MAIWP dalam penyata kewangan dapat dilihat dalam tiga keadaan iaitu:

a) Hanya wakaf tunai diambil kira dalam penyata kewangan MAIWP, manakala harta wakaf yang lain seperti tanah dan bangunan tidak dilaporkan.

b) MAIWP telah menubuhkan syarikat subsidiari iaitu Pusat Wakaf Sdn Bhd pada tahun 2014 untuk menguruskan kutipan wakaf bagi pihak MAIWP. Penyata kewangan Pusat Wakaf Sdn Bhd akan disatukan dengan penyata kewangan MAIWP pada setiap tahun.

c) MAIWP mewujudkan Wakaf Ahmad Dawjee Dadabhoy yang diakaunkan secara berasingan dan tidak disatukan dengan penyata kewangan MAIWP.

Selain itu, aspek pewartaan harta wakaf pada setiap akhir tahun juga masih belum dilaksanakan di MAIWP. Masalah yang dikenal pasti ialah pegawai tidak mempunyai rujukan piawaian pelaporan kewangan yang khusus untuk wakaf dan tiada garis panduan bagi perakaunan wakaf. Jabatan Audit Negara melalui Laporan Ketua Audit Negara Tahun 2014 juga telah menegur Majlis Agama Islam Negeri Kedah dan Kelantan kerana tidak menyediakan senarai dan menyiarkan dalam Warta harta wakaf mengikut enakmen negeri masingmasing. Mengikut Laporan Ketua Audit Negara Negeri Kedah Tahun 2014, harta wakaf tidak disenarai dan disiarkan dalam warta sebaliknya diambil kira sebagai aset dalam penyata kewangan Majlis Agama Islam Negeri Kedah yang dibentangkan di Dewan Undangan Negeri. ${ }^{52}$

Begitu juga dengan Majlis Agama Islam Negeri Kelantan yang beranggapan bahawa pewartaan penyata kewangan yang beraudit pada setiap tahun yang merangkumi harta dan aset zakat, baitulmal dan wakaf adalah memadai. ${ }^{53}$ Mereka juga tidak menyedari adanya keperluan mewartakan harta wakaf seperti yang termaktub dalam enakmen. Secara jelasnya, wujud tidak ketidakseragaman pelaporan wakaf oleh MAIWP berbanding Majlis Agama Islam Negeri Kedah dan Majlis Agama Islam Negeri Kelantan.

Kajian mengenai pelaporan wakaf, zakat dan Baitulmal di Malaysia menyatakan data menunjukkan bahawa perbezaan dalam model tadbir urus boleh memberi impak secara langsung terhadap amalan perakaunan dan

52 Jabatan Audit Negara, 'Laporan Ketua Audit Negara Negeri Kedah 2014,' 16, https://www.audit.gov.my, dicapai pada 15 April 2018.

53 Jabatan Audit Negara, 'Laporan Ketua Audit Negara Negeri Kelantan 2014,' 45, https://www.audit.gov.my, dicapai pada 15 April 2018. 
Pembangunan Tanah Wakaf Secara Penswastaan: Kajian Terhadap Projek Menara Imarah Wakaf oleh Majlis Agama Islam Wilayah Persekutuan

pelaporan kewangan bagi institusi-institusi berkenaan. ${ }^{54}$ Kajian yang dibuat terhadap empat MAIN mendapati kesemuanya menggunakan piawaian perakaunan yang berbeza-beza dan satu MAIN menyediakan penyata kewangan yang berasingan untuk zakat. Responden kajian memaklumkan perbezaan ini berlaku kerana tiada piawaian perakaunan yang sama digunakan sebagai asas penyediaan laporan kewangan oleh setiap institusi wakaf, zakat dan baitulmal yang terlibat. Empat piawaian perakaunan yang digunakan iaitu Private Entity Reporting Standard (PERS), Malaysian Private Entity Reporting Standard (MPERS), Malaysia Public Sector Accounting Standard (MPSAS) dan International Accounting Standard (IAS). Pengkaji berpendapat adalah penting untuk mengadakan sistem perakaunan yang teratur yang boleh digunakan oleh kesemua MAIN supaya penilaian dan perbandingan prestasi MAIN dapat dilakukan. ${ }^{55}$

Pengagihan sumber pendapatan hasil daripada pembangunan harta wakaf yang dilaksanakan di Malaysia hendaklah memfokuskan lima tema utama iaitu keagamaan, pendidikan, kesihatan, kebajikan dan ekonomi. ${ }^{56}$ Berdasarkan hasil pajakan yang diterima oleh MAIWP bagi tempoh 25 tahun berjumlah RM56.60 juta, ianya dapat dimanfaatkan sepenuhnya oleh orang Islam khususnya sekiranya MAIWP membuat perancangan pengagihan yang teliti. Majoriti pembangunan hartanah yang dijalankan adalah cenderung kepada pembangunan yang berkonsepkan Islam dan keagamaan sematamata. ${ }^{57}$ Berdasarkan ucaptama Gabenor Bank Negara Malaysia semasa forum Waqf: An Economic Perspective, beliau menyatakan wakaf boleh memainkan peranan penting untuk membangunkan ekonomi yang dinamik, progresif dan inklusif dengan menyelesaikan sebahagian daripada cabaran yang dihadapi oleh masyarakat seperti isu ketaksamaan dan menambahbaik

54 Abdullah Abdul Ghani, Rohami Shafie, Md. Suhaimi Md. Salleh, Faisol Ilham, Muhamad Hanif Abdul Kadir, Mohamad Sharofi Ismail, Fathilatul Zakimi Abdul Hamid, Nasri Naimi \& Zaleha Othman, 'Isu-isu dalam Pengurusan dan Pelaporan Wakaf, Zakat dan Baitulmal bagi Institusi Wakaf, Zakat dan Baitulmal di Malaysia,' 46.

55 Maliah Sulaiman, Muslim Har Sani Mohamad, Hafiz Majdi Abdul Rashid, Ahmad Zamri Osman, Siti Alawiah Siraj \& Ibrahim Nunu, 'Accounting And Accountability of Waqf, Zakat and Baitul Mal in Malaysia,' 1-12.

56 Hydzulkifli Hashim Omar \& Asmak Ab Rahman, Pembiayaan Pembangunan Harta Wakaf Menggunakan Sukuk (Kuala Lumpur: Universiti Malaya, 2015), 141.

57 Rohayu Abdul Majid \& Rosli Said, 'Permasalahan Pengurusan Hartanah Wakaf di Malaysia,' 33. 
kualiti pendidikan dan kesihatan. ${ }^{58}$ Manfaat terhadap aset wakaf juga dapat disalurkan untuk kebajikan umum yang melibatkan masyarakat bukan Islam seperti derma kepada yayasan kanser atau rumah warga emas tanpa mengira latar belakang agama..$^{59}$

MAIWP juga akan mengambil kira penggantian harta wakaf iaitu istibdal dengan menggunakan hasil sewa pajakan tanah. Perkara ini selaras dengan pandangan Mufti Wilayah Persekutuan mengenai syarat pembangunan tanah wakaf yang menyatakan perlu ada gantian yang berkekalan juga di samping unit-unit bangunan yang ditawarkan. Salah satu aspek yang perlu diberi perhatian dalam pembangunan wakaf adalah wakaf istibdal iaitu menukar sesuatu harta wakaf yang tidak produktif dengan yang lain, dari jenis sama tetapi mengandungi nilai yang lebih baik, sama ada melalui pertukaran, jualan atau belian dengan mengekalkan tujuan asal manfaatnya supaya pahala berterusan kepada pewakaf. ${ }^{60}$ Ia juga dapat mengatasi masalah harta wakaf yang terbiar dan tidak dibangunkan disebabkan lokasi dan keluasan terhad sedangkan harta wakaf tersebut bernilai tinggi.

Pengurusan harta wakaf di Wilayah Persekutuan oleh MAIWP adalah berdasarkan Seksyen 61 hingga 68, Akta Pentadbiran Undang-undang Islam (Wilayah-wilayah Persekutuan) 1993 (Akta 505). Empat buah negeri yang telah menggubal enakmen wakaf negeri ialah Perak, Melaka, Negeri Sembilan dan Selangor manakala bagi negeri lain pengurusan harta wakaf dinyatakan dalam peruntukan enakmen/akta pentadbiran undang-undang Islam negeri. ${ }^{61}$ Bagi negeri Johor pula, pengurusan wakaf dilaksanakan melalui Kaedahkaedah Wakaf 1983. Enakmen wakaf adalah sangat signifikan kerana enakmen pentadbiran agama Islam atau Undang-undang Islam negeri tidak mempunyai peruntukan pengurusan wakaf yang terperinci. Sebagai contoh Akta Pentadbiran Undang-undang Islam (Wilayah-wilayah Persekutuan) 1993 (Akta 505) hanya menyatakan peruntukan MAIWP sebagai pemegang amanah dan kaedah perletakkan hak harta amanah, wakaf dan nazar.

Peruntukan dalam enakmen wakaf lebih terperinci contohnya Enakmen Wakaf (Negeri Selangor) 2015 mempunyai 10 bahagian yang antaranya

$58 \quad$ The Edge Markets, 'Waqf Can Develop More Dynamic, Progressive, Inclusive Economy’, https://www.theedgemarkets.com, dicapai pada 10 April 2018.

59 Hydzulkifli Hashim Omar \& Asmak Ab Rahman, Pembiayaan Pembangunan Harta Wakaf Menggunakan Sukuk (Kuala Lumpur: Universiti Malaya, 2015), 141.

60 Hailani Muji Tahir \& Jaafar Ahmad, 'Mekanisme Istibdal dan Pembiayaan Hartanah Wakaf', Jurnal Penyelidikan Islam, vol. 17 (2004): 109- 124.

${ }^{61}$ Syarifah Zubaidah Syed Abdul Kadir, 'Kerangka Undang-Undang Pengurusan Wakaf di Malaysia: Ke Arah Keseragaman Undang-Undang,' 105. 
terdiri daripada kuasa dan tanggungjawab Majlis, pelantikan Pendaftar Wakaf, pewujudan wakaf dari aspek rukun-rukun wakaf, wakaf sebagai wasiat, kumpulan wang wakaf dan penentuan hukum syarak. Negeri yang mempunyai enakmen wakaf yang khusus mempunyai struktur pengurusan wakaf yang lebih baik berbanding dengan negeri yang tidak mempunyai enakmen tersebut. ${ }^{62}$ Selaras dengan perkembangan dan pertambahan harta wakaf di Wilayah Persekutuan, keperluan terhadap enakmen wakaf oleh MAIWP adalah sangat signifikan.

Sehubungan itu, MAIWP boleh mempertimbangkan untuk merangka akta wakaf bagi memantapkan pengurusan wakaf di Wilayah Persekutuan sepertimana yang dilaksanakan oleh MAIN Perak, Melaka, Negeri Sembilan dan Selangor. Ini adalah kerana pada masa ini MAIWP tidak mempunyai kerangka perundangan yang terperinci untuk pengurusan harta wakaf secara menyeluruh. Manual Pengurusan Tanah Wakaf (2008) yang disediakan oleh JAWHAR hanya untuk pentadbiran sahaja. ${ }^{63}$ Kandungannya pula tidak meliputi pengurusan tanah wakaf secara menyeluruh iaitu hanya mengandungi bahagian Pengurusan Pendaftaran Tanah Wakaf dan Pengurusan \& Pentadbiran Tanah Wakaf. Selain itu, keperluan untuk melaporkan harta wakaf dalam penyata kewangan perlu dinyatakan dalam enakmen wakaf. MAIWP juga perlu mengambil kira keperluan pendaftaran bangunan wakaf bagi memenuhi rukun wakaf.

Keperluan kerangka pelaporan wakaf adalah kritikal berikutan kerangka pelaporan kewangan di Malaysia yang sedia ada adalah lebih sesuai untuk tujuan komersial. Jabatan Akauntan Negara Malaysia telah mengambil peranan untuk membangunkan kerangka dan piawaian pelaporan wakaf dan usaha sedang dilaksanakan. Inisiatif yang dilaksanakan oleh Jabatan Akauntan Negara Malaysia yang berkolaborasi dengan Universiti Kebangsaan Malaysia, Universiti Utara Malaysia dan Universiti Islam Antarabangsa untuk membangunkan kerangka dan piawaian pelaporan dan perakaunan adalah tepat pada masanya dan signifikan untuk perkembangan pelaporan penyata kewangan oleh MAIN. ${ }^{64}$ Ini disokong oleh kajian yang menyatakan pakar daripada bidang perakaunan dan syariah perlu menjalinkan kerjasama supaya

62 Syarifah Zubaidah Syed Abdul Kadir, 'Kerangka Undang-Undang Pengurusan Wakaf di Malaysia: Ke Arah Keseragaman Undang-Undang,' 110.

63 Jabatan Wakaf, Haji dan Zakat (JAWHAR), 'Manual Pengurusan Tanah Wakaf JAWHAR 2008', www.jawhar.gov.my, dicapai pada 30 April 2018.

64 Bernama, 'Piawaian Perakaunan Islam Untuk Pelaporan Kewangan Wakaf, Zakat dan Baitulmal Dibentuk,' https://www.bernama.com, dicapai pada 4 Februari 2018 . 
aspek perakaunan dan pelaporan dapat diselaraskan mengikut Syariah. ${ }^{65}$ Dengan adanya kolaborasi antara pelaksana dan pakar dalam bidang perakaunan dan Syariah dijangka dapat mempercepatkan pembangunan kerangka dan piawaian pelaporan \& perakaunan untuk wakaf khususnya.

\section{KESIMPULAN}

Pembangunan tanah wakaf secara penswastaan adalah salah satu alternatif untuk mengatasi masalah tanah wakaf tidak dibangunkan kerana kekurangan dana institusi wakaf dan kekurangan kepakaran dalam pengurusan projek. Kaedah pembangunan ini dapat menambah hartanah wakaf di mana Menara Imarah Wakaf akan ditukar hak milik pada akhir tempoh 25 tahun. Beban institusi wakaf dalam membiayai kos pembangunan dapat dikurangkan dan skil yang efisien dalam pengurusan projek dapat diaplikasikan oleh institusi wakaf apabila projek dipulangkan kepada mereka. ${ }^{66}$ Dengan perkongsian pintar antara MAIWP dan Lembaga Tabung Haji telah mewujudkan sinergi dan memberi keuntungan kepada semua pihak. Hasil pajakan yang diterima oleh MAIWP dapat diagihkan kepada masyarakat dan memberi manfaat kepada semua. Pembelian harta gantian menggunakan hasil sewa pajakan iaitu istibdal dapat memberi pahala yang berterusan kepada pewakaf. Bagi Lembaga Tabung Haji, wang yang disimpan oleh pendeposit dapat dilaburkan dan memberi pulangan kepada pendeposit sebagai tambahan deposit untuk mereka menunaikan haji. Pihak Bank Islam pula mendapat manfaat penyewaan di bangunan yang direka bentuk khusus untuk institusi perbankan dan penyewaan dapat dibuat dalam tempoh yang panjang. Berdasarkan kajian yang dibuat, model penswastaan ini mematuhi syarak dan boleh dijadikan rujukan oleh institusi wakaf supaya pembangunan tanah wakaf dapat dibuat dengan cekap dan berkesan serta dapat menambah harta wakaf untuk manfaat umum.

Bagaimanapun, penambahbaikan perlu dibuat terhadap pelaporan wakaf bagi meningkatkan akauntabiliti dan ketelusan dalam penggunaan harta wakaf. Selain dapat memberi keyakinan kepada waris pewakaf, ia juga dapat menggalakkan masyarakat untuk berwakaf seterusnya memberi manfaat kepada masyarakat keseluruhannya. Selain itu, enakmen wakaf juga dapat

${ }_{65}$ Maliah Sulaiman, Muslim Har Sani Mohamad, Hafiz Majdi Abdul Rashid, Ahmad Zamri Osman, Siti Alawiah Siraj \& Ibrahim Nunu, 'Accounting And Accountability of Waqf, Zakat and Baitul Mal in Malaysia,' 8.

66 Azman Mat Noor \& Saidatolakma Mohd Yunus, 'Penggunaan Akad Build, Operate and Transfer Sebagai Cara Pembiayaan (Kewangan) dalam Membangunkan Tanah Wakaf Oleh Majlis Agama Islam Wilayah Persekutuan: Satu Analisis Mengikut Perspektif Syariah,' 11. 
Pembangunan Tanah Wakaf Secara Penswastaan: Kajian Terhadap Projek Menara Imarah Wakaf oleh Majlis Agama Islam Wilayah Persekutuan

membantu MAIWP untuk meningkatkan kecekapan dalam pengurusan harta wakaf di Wilayah Persekutuan. Perancangan pengagihan wakaf yang teliti dengan mengenal pasti keperluan masyarakat dengan mengutamakan bidang pendidikan dan kesihatan perlu diberi perhatian. Ini bukan sahaja memenuhi kehendak pewakaf tetapi pada masa yang sama instrumen wakaf dapat dijadikan alat untuk membangunkan ekonomi yang dinamik dan progresif. Adalah dicadangkan kajian dibuat pada masa hadapan oleh penyelidik terhadap mekanisme pengagihan wakaf yang efektif dengan mengenal pasti dan mengutamakan keperluan masyarakat supaya pengagihan yang dibuat dapat memenuhi keperluan kebajikan umat Islam di Malaysia. Wakaf perlu dilihat sebagai pemangkin pembangunan ekonomi negara terutamanya dalam mengurangkan kadar kemiskinan menerusi agihan semula kekayaan, menyediakan perkhidmatan kesihatan, pendidikan, penubuhan pusat anak yatim dan keperluan masyarakat yang lain.

\section{RUJUKAN}

Abdullah Abdul Ghani, Rohami Shafie, Md. Suhaimi Md. Salleh, Faisol Ilham, Muhamad Hanif Abdul Kadir, Mohamad Sharofi Ismail, Fathilatul Zakimi Abdul Hamid, Nasri Naimi \& Zaleha Othman, 'Isu-isu dalam Pengurusan dan Pelaporan Wakaf, Zakat dan Baitulmal bagi Institusi Wakaf, Zakat dan Baitulmal di Malaysia,' IPN Journal of Research and Practice in Public Sector Accounting and Management, vol. 7 (2017): 41-51.

Afiffudin Mohammed Noor, Rusnadevi Abdul Rashid, Rohayati Hussin \& Noor Inayah Yaakub, 'Aplikasi Konsep Pajakan dalam Pembangunan Tanah Wakaf di Negeri Kedah Darul Aman,' Muktamar Waqf Iklimi II (Nilai: Universiti Sains Islam Malaysia, 2015).

Asmak Ab Rahman, 'Peranan Wakaf dalam Pembangunan Ekonomi Umat Islam dan Aplikasinya di Malaysia,' Jurnal Syariah, vol. 17/1 (2009): 113-152.

Azizan, Hydzulkifli \& Mohd Sollehudin, 'Kaedah Pengurusan Harta MAIK: Pelaksanaan Pajakan Untuk 99 Tahun,' International Journal of Management Studies, vol. 23/1 (2016): 73-89.

Azman Mat Noor \& Saidatolakma Mohd Yunus, 'Penggunaan Akad Build, Operate and Transfer Sebagai Cara Pembiayaan (Kewangan) dalam Membangunkan Tanah Wakaf Oleh Majlis Agama Islam Wilayah Persekutuan: Satu Analisis Mengikut Perspektif Syariah', Jurnal Muamalat, vol. 4 (2011): 1-30. 
Bernama, 'Piawaian Perakaunan Islam Untuk Pelaporan Kewangan Wakaf, Zakat dan Baitulmal Dibentuk,' https://www.bernama.com, dicapai pada 4 Februari 2018.

Hailani Muji Tahir \& Jaafar Ahmad, 'Mekanisme Istibdal dan Pembiayaan Hartanah Wakaf', Jurnal Penyelidikan Islam, vol. 17 (2004): 109-124.

Hairul Suhaimi Nahar Hisham Yaacob, 'Accountability in the Sacred Context: The Case of Management, Accounting and Reporting of A Malaysian Cash Awqaf Institution,' Journal of Islamic Accounting and Business Research, vol. 2/2 (2011): 87-113.

Hajah Mustafa Mohd Hanefah, Abdullah Jalil, Asharaf Mohd Ramli, Hisham Sabri, Norhaziah Nawai \& Syahidawati Shahwan, 'Financing The Development of Waqf Property: The Experience of Malaysia and Singapore,' The Journal of Muamalat and Islamic Finance Research, vol. 8/1 (2011): 89-103.

Hisham Yaacob, Saerah Petra, Azizah Sumardi \& Hairul Suhaimi, 'Accountability Through Accounting And Reporting Lenses: Lessons From An Awqaf Institution in A Southeast Asia Country,' Humanomics, vol. 31/3 (2015): 299-313.

Hydzulkifli Hashim \& Asmak Abdul Rahman, 'Pengurusan Pembangunan Harta Wakaf: Pengalaman Majlis Agama Islam Negeri Pulau Pinang,' International Journal of Management Studies, vol. 19/2 (2012): 103123.

Hydzulkifli Hashim Omar \& Asmak Ab Rahman, Pembiayaan Pembangunan Harta Wakaf Menggunakan Sukuk (Kuala Lumpur: Penerbit Universiti Malaya, 2015).

Hydzulkifli Hashim Omar, Azizi Abu Bakar, Mohd Sollehudin Shuib \& Mohd Kamal Azman Jusoh, 'Penggunaan Kaedah Bot dalam Usaha Membangunkan Tanah Wakaf Majoodsaw Pulau Pinang,' The Islamic Endowment Seminar (Nilai: Universiti Sains Islam Malaysia, 2014).

Jabatan Audit Negara, 'Laporan Ketua Audit Negara Negeri Kedah 2014,' https://www.audit.gov.my, dicapai pada 15 April 2018.

Jabatan Audit Negara, 'Laporan Ketua Audit Negara Negeri Kelantan 2014,' https://www.audit.gov.my, dicapai pada 15 April 2018.

Jabatan Kemajuan Islam Malaysia, 'Kompilasi Pandangan Hukum, Muzakarah Jawatankuasa Fatwa Majlis Kebangsaan Bagi Hal Ehwal Ugama Islam,' https:// www.islam.gov.my, dicapai pada 15 April 2018.

Jabatan Wakaf, Haji dan Zakat (JAWHAR), 'Manual Pengurusan Tanah Wakaf JAWHAR 2008', http://www.jawhar.gov.my, dicapai pada 30 April 2018. 
Pembangunan Tanah Wakaf Secara Penswastaan: Kajian Terhadap Projek Menara Imarah Wakaf oleh Majlis Agama Islam Wilayah Persekutuan

Majlis Agama Islam Wilayah Persekutuan, Laporan Tahunan (Kuala Lumpur: MAIWP, 2016).

Maliah Sulaiman, Muslim Har Sani Mohamad, Hafiz Majdi Abdul Rashid, Ahmad Zamri Osman, Siti Alawiah Siraj \& Ibrahim Nunu, 'Accounting And Accountability of Waqf, Zakat and Baitul Mal in Malaysia', IPN Journal of Research and Practice in Public Sector Accounting and Management, vol. 6 (2016): 1-12.

Maznah Zakaria, Mohd Sabri Hassan \& Radziah Abdul Latif, 'Pelaporan Wakaf di Malaysia: Mengenal Pasti Keperluan Maklumat Pemegang Kepentingan', Prosiding Persidangan Kebangsaan Ekonomi Malaysia ke-9 (Bangi: Universiti Kebangsaan Malaysia, 2014).

Mohamad Zaim Ismail, Khader Ahmad, Mohd Farhan Md. Ariffin \& Muhammad Ikhlas Rosele, 'Pemerkasaan Wakaf di Malaysia: Satu Sorotan,' Paper Proceeding of the 5th Islamic Economics System Conference (Nilai: Universiti Sains Islam Malaysia, 2013).

Mohammad Tahir Sabit Mohammad, 'Alternative Development Financing Instruments for Waqf Properties,' Malaysian Journal of Real Estate Volume, 4/2 (2009): 45-57.

Mohd Fairuz Md Salleh, Azlina Ahmad, Norida Basnan, Azizah Harun, Hairunnizam Wahid \& Ainol Basirah Abdul Wahab, 'Disclosure of NonFinancial Information in Discharging Accountability of Waqf Trustee,' IPN Journal of Research and Practice in Public Sector Accounting and Management, vol. 7 (2017): 15-27.

Mohd Fairuz Md Salleh, Norida Basnan, Azlina Ahmad, Azizah Harun, Muhammad Arzim Naim \& Hairunnizam Wahid, 'Cadangan Item Pendedahan Bagi Pelaporan Institusi Wakaf, Zakat dan Baitulmal,' IPN Journal of Research and Practice in Public Sector Accounting and Management, vol. 6 (2016): 23-44.

Mohd Haiyazid Mohammad \& Sanep Ahmad, 'Pembangunan Tanah Wakaf Melalui Hotel Wakaf: Strategi Lautan Biru Nasional,' (The Asean Islamic Endowment Seminar 2014), 563-573.

Muhammad Abdurrahman Sadique, 'Development of Dormant Waqf Properties: Application of Traditional and Contemporary Modes of Financing', IIUM Law Journal, vol. 18/1 (2010): 75-103.

Mușțafā Bughā, Mukhtașṣar Șahīh Muslim, terj. Muhammad Amar Adly et al. (Johor: Binhalabi Press, 2013). 
Nurul Azma Abu Bakar, Muhammad Nasri Md Hussain \& Abu Bakar Hamed, 'Kaedah Pembangunan Tanah Wakaf Oleh Majlis Agama Islam dan Adat Melayu Perak (MAIPK),' Journal of Islamic, Sosial, Economics and Development, vol. 2/4 (2017): 1-10.

Osman Sabran, Pengurusan Harta Wakaf, Wakaf (Skudai: Penerbit UTM, 2002).

Rohayati Hussin \& Rusnadewi Abdul Rashid, 'Isu-Isu Berkaitan Tanah Wakaf Halangan Kepada Institusi Wakaf Pendidikan Tinggi di Malaysia,' (Kertas kerja, Waqf Round Table Conference, 2015).

Rohayati Hussin, Rusnadevi Abdul Rashid \& Noor Inayah Yaakub, 'Ke Arah Pembangunan Institusi Pendidikan Tinggi Wakaf: Kajian Dari Aspek Perundangan Tanah Negara, (Kertas Kerja, 9th ISDEV International Islamic Development Management Conference, 2015).

Rohayu Abdul Majid \& Rosli Said, 'Permasalahan Pengurusan Hartanah Wakaf di Malaysia,' International Surveying Research Journal, vol. 4/1 (2014): 29-43.

Rusnadewi Abdul Rashid, Rohayati Hussin \& Noor Inayah Yaakub, 'Pendaftaran Tanah Wakaf dari Perspektif Perundangan', Muktamar Waqf Iklimi II (Nilai: Universiti Sains Islam Malaysia, 2015).

Sanep Ahmad \& Nur Diyana Muhamed, 'Institusi Wakaf dan Pembangunan Ekonomi Negara: Kes Pembangunan Tanah Wakaf di Malaysia,' Prosiding Persidangan Kebangsaan Ekonomi Malaysia ke VI (Bangi: Universiti Kebangsaan Malaysia, 2011).

Syarifah Zubaidah Syed Abdul Kadir, 'Kerangka Undang-Undang Pengurusan Wakaf di Malaysia: Ke Arah Keseragaman Undang-Undang,' Kanun: Jurnal Undang-Undang Malaysia, vol. 28/1 (2016): 101-126.

The Edge Markets, 'Waqf Can Develop More Dynamic, Progressive, Inclusive Economy’, https://www.theedgemarkets.com, dicapai pada 10 April 2018.

Wahbah al-Zuhaily, Fiqh \& Perundangan Islam Jilid VIII, terj. Ahmad Shahbari Salamon et al. (Kuala Lumpur: Dewan Bahasa dan Pustaka, 2011).

Yayasan Wakaf Malaysia, 'Laporan Tahunan Yayasan Wakaf Malaysia 2016,' https://ywm.gov.my, dicapai pada 30 April 2018. 
Pembangunan Tanah Wakaf Secara Penswastaan: Kajian Terhadap Projek Menara Imarah Wakaf oleh Majlis Agama Islam Wilayah Persekutuan

\section{Statut}

Akta Undang-Undang Pentadbiran Islam (Wilayah-wilayah Persekutuan)1993 Enakmen Wakaf (Negeri Selangor) 2015

Perlembagaan Persekutuan 
Jurnal Syariah, Jil. 27, Bil. 1 (2019) 45-76 